\title{
KESELAMATAN KAPAL PENANGKAP IKAN, TINJAUAN DARI ASPEK REGULASI NASIONAL DAN INTERNASIONAL
}

\author{
(Fishing Vessel Safety from National and International Regulations Point of View)
}

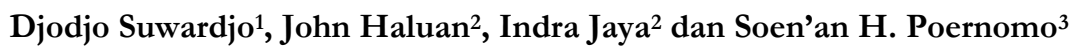

\begin{abstract}
Fishing is a high risk occupation compared to other occupations. Charachteristics of the occupational in fishing vessel are dangerous, dirty and difficult, known as "3d". Generally, fishing vessels size is relatively small size, majority under $24 \mathrm{~m}$ length, sailing and fishing in bad weather with rough sea with unskilled crews, so that those factors can increase the fatality rate of the fishing vessel crews. Fishing vessel safety is a complex interactions among human factor (skipper and crew's members), machines (fishing vessel and safety equipment) and environmental (weather and fisheries management). Fishing safety problems emerge when minimum one of those elements of human factor, machines or environment is misfucntion. The objectives of this research is to identify national and international safety regulations for fishing vessel and also relationship between fishing vessel and merchant vessel safety policies in Indonesia. Research was carried out from May 2008 - March 2009. Data was collected from any kind of source, such as Agency for Marine and Human Resource Development, Directorate General of Capture Fisheries, Tegal Coastal Fishing Port, Pekalongan Archipelago Fishing Port, Cilacap Ocean Fishing Port and Ministry of Communication. Fishing vessel safety policy basically is based on fishing vessel's seaworthiness, watchkeeping/ship manning, safety equipment, and pollution prevention from the ship activities in national level as well as international level. Fishing vessel seaworthiness and watchkeeping/ship manning policies as a control function from the goverment to the parties involved in fishing activities to increase safety of crews, fishing vessel and sea environment from fishing vessel activities. Due to the characteristics of the working conditions on fishing vessel, more complex social environment of the fishermen and great number of fishermen in Indonesia, regulations on fishing vessel safety; watchkeeping/ship manning; works in fishing; education, training and certification of fishing vessel personnel; and fishing port, should be separated from the merchant ship safety regulations as international organizations did.
\end{abstract}

Keywords : fishing vessel safety, watchkeeping/ship manning, human factor, machines, environment, education and training, certification, separated regulation

\begin{abstract}
ABSTRAK
Pekerjaan pada kapal penangkap ikan merupakan pekerjaan yang tergolong membahayakan dibanding pekerjaan lain, maka profesi pelaut kapal penangkap ikan memiliki karakteristik pekerjaan " $3 \mathrm{~d}$ ” yaitu: membahayakan (dangerous), kotor (dirty) dan sulit (difficult) dengan ketiga sifat pekerjaan tersebut ditambah faktor ukuran kapal yang didominasi kapal-kapal berukuran relatif kecil, berlayar pada perairan gelombang tinggi dengan kondisi cuaca tidak menentu sehingga dapat meningkatkan tingkat kecelakaan kapal penangkap ikan. Keselamatan kapal penangkap ikan merupakan interaksi faktor-faktor yang kompleks, yakni buman factor (nakhoda dan anak buah kapal), machines (kapal dan peralatan keselamatan) dan enviromental (cuaca dan skim pengelolaan sumberdaya perikanan). Permasalahan keselamatan atau kecelakaan akan timbul apabila salah satu elemen dari human factor, machines atau enviromental factor tersebut tidak berfungsi. Penelitian bertujuan mengidentifikasi peraturan keselamatan kapal penangkap ikan pada tingkat nasional dan internasional serta keterkaitan kebijakan keselamatan kapal penangkap ikan dan kapal niaga. Penelitian dilaksanakan Mei 2008 - Maret 2009. Data primer diperoleh dari berbagai sumber, seperti Badan Pengembangan Sumberdaya Manusia Kelautan dan Perikanan, Direktorat Jenderal Perikanan Tangkap, Pelabuhan Perikanan Pantai (PPP) Tegal Sari Kota Tegal, Pelabuhan Perikanan Nusantara (PPN) Pekalongan, Pelabuhan Perikanan Samudera (PPS) Cilacap dan Kementerian Perhubungan. Kebijakan keselamatan kapal penangkap ikan pada dasarnya mencakup kebijakan kelaikan kapal, dinas jaga kapal/pengawakan kapal, dan pencegahan polusi laut dari kegiatan kapal penangkap ikan, baik pada tataran nasional maupun internasional. Pengaturan kelaikan dan dinas jaga kapal/pengawakan kapal penangkap ikan merupakan pengawasan atau kontrol dari pemerintah terhadap pihak yang terlibat dalam kegiatan penangkapan ikan untuk meningkatkan keselamatan jiwa, harta benda dan lingkungan laut. Mengingat karakteristik pekerjaan pada kapal penangkap ikan membahayakan awak kapal dan lingkungan sosial lebih kompleks, serta jumlah nelayan yang begitu banyak, maka di Indonesia, pengaturan tentang kelaiklautan kapal, dinas jaga kapal/pengawakan kapal, pendidikan, pelatihan dan sertifikasi awak kapal, kepelautan kapal perikanan dan pelabuhan perikanan sebaiknya diatur tersendiri, sebagaimana pengaturan pada tataran internasional telah diatur terpisah dari pengaturan kapal niaga.
\end{abstract}

Kata kunci: keselamatan kapal penangkapan ikan, dinas jaga kapal, kesalahan manusia, mesin, lingkungan, pendidikan dan pelatihan, sertifikasi, peraturan

\footnotetext{
${ }^{1}$ Staf Ditjen P2HP, Kementrian Kelautan dan Perikanan

${ }^{2}$ Staf Departemen Pemanfatan Sumberdaya Perikanan, FPIK- IPB

${ }^{3}$ Kepala Pusat Statistik dan Informasi, Sekjen Kementrian Kelautan dan Perikanan
} 


\section{PENDAHULUAN}

Kegiatan penangkapan ikan di laut merupakan pekerjaan yang paling membahayakan di dunia. Profesi pelaut kapal penangkap ikan memiliki karakteristik pekerjaan "3d" yaitu: membahayakan (dangerous), kotor (dirty) dan sulit (difficult) (FAO, 2000), dengan ketiga sifat pekerjaan tersebut ditambah faktor ukuran kapal yang umumnya relatif kecil pada kondisi cuaca dan gelombang laut besar yang semakin tidak menentu akibat adanya pemanasan global maka tingkat kecelakaan kapal penangkap ikan semakin lebih tinggi.

Tingginya tingkat kecelakaan fatal (meninggal) kapal penangkap ikan di dunia, rata-rata 80 orang per 100.000 orang awak kapal meningkatkan perhatian badan internasional seperti IMO, FAO dan ILO terhadap pentingnya peningkatan keselamatan dan ketenagakerjaan pada kapal penangkap ikan. Badan-badan dunia tersebut dengan melibatkan pihak tripartit, yakni pihak pemerintah, pemilik kapal dan pelaut perikanan telah mengadopsi suatu konvensi yang berkaitan dengan ketenagakerjaan yang layak (decent work).

Di Indonesia, pendataan kecelakaan kapal penangkap ikan belum dilaksanakan terstruktur. Hasil penelitian di PPP Tegalsari, PPN Pekalongan dan PPS Cilacap pada tiga tahun terakhir (2006-2008) telah terjadi 61 kecelakaan fatal (menyebabkan awak kapal meninggal/ hilang) sebanyak 68 orang nelayan dari sejumlah 58.919 nelayan aktif. Tingkat kecelakaan fatal di ketiga lokasi tersebut setara dengan 115 orang meninggal per 100.000 orang nelayan aktif pertahun. Tingkat kecelakaan tersebut lebih tinggi dari rata-rata kecelakaan fatal kapal penangkap ikan tingkat dunia 80 orang meninggal per 100.000 orang nelayan. Kerugian harta benda berupa kapal dan perlengkapannya serta alat tangkap ikan hilang di laut tercatat sebanyak 22 unit.

Penyebab kecelakaan fatal awak kapal adalah rendahnya kesadaran awak kapal tentang keselamatan kerja pada pelayaran dan kegiatan penangkapan, rendahnya penguasaan kompetensi keselamatan pelayaran dan penangkapan ikan, kapal tidak dilengkapi peralatan keselamatan sebagaimana seharusnya, cuaca buruk seperti gelombang besar dan menderita sakit keras dalam pelayaran.

Awak kapal perikanan laut termasuk nelayan tradisional di Indonesia berjumlah kurang lebih 2,78 juta orang mengawaki armada penangkapan sebanyak 555.940 unit kapal penangkap ikan (Dirjen Perikanan Tangkap, 2008). Jumlah awak kapal di Indonesia tersebut $10 \%$ dari populasi nelayan seluruh dunia.

Tingginya tingkat kecelakaan awak kapal penangkap ikan memerlukan perhatian lebih serius melalui pengaturan standar minimum pengetahuan dan keterampilan awak kapal penangkap ikan, standar kapal penangkap ikan, standar alat tangkap ikan, standar pengawakan kapal penangkap ikan, standar operasi penangkapan ikan, standar ketenagakerjaan pada kapal penangkap ikan. Standar tersebut harus disesuaikan dengan ukuran kapal, daya mesin utama kapal, daerah pelayaran dan teknologi penangkapan yang digunakan.

Keselamatan kapal penangkap ikan merupakan interaksi faktor-faktor yang kompleks, yakni human factor (nakhoda dan Anak Buah Kapal), machines (kapal dan peralatan keselamatan) dan enviromental (cuaca dan skim pengelolaan sumberdaya perikanan). Permasalahan keselamatan atau kecelakaan akan timbul apabila minimum satu elemen dari human factor, machines atau enviromental factor tersebut tidak berfungsi (Lincoln et al., 2002).

Kebijakan pengaturan keselamatan kapal penangkap ikan pada dasarnya adalah kebijakan kelaikan kapal dan pengawakan kapal penangkap ikan. Kapal penangkap ikan harus memenuhi kelaiklautan dan laik operasi penangkapan. Laiklaut meliputi laik kapal dan laik pengawakan kapal sementara laik operasi penangkapan meliputi laik alat tangkap, daerah penangkapan dan penanganan hasil tangkap.

Kebijakan internasional tentang keselamatan jiwa dan kapal penangkap ikan lebih diutamakan penerapannya kepada awak kapal dan kapal-kapal penangkap ikan berukuran panjang kapal pada garis air (LWL) $24 \mathrm{~m}$ atau lebih, setara panjang keseluruhan kapal (LOA) 26,5 $\mathrm{m}$ atau lebih. Pada peraturan internasional Works in Fishing Convention Nomor 188, panjang kapal 24 m setara dengan 300 GT.

Permasalahan pengaturan kebijakan kelaiklautan kapal penangkap ikan, pengaturan pengawakan awak kapal, ketenagakerjaan pada kapal penangkap ikan diatur secara bersamaan dengan pengaturan awak kapal, keselamatan kapal dan ketenagakerjaan pada kapal niaga sehingga menimbulkan persepsi yang beragam. Hal ini me- 
rupakan permasalahan dalam implementasi di tingkat operasional.

Mengingat karakteristik pekerjaan pada kapal penangkap ikan sangat berbeda dengan lainnya maka upaya pencegahan dan mitigasi risiko kecelakaan melalui peraturan keselamatan disarankan pengaturan standar minimum pengetahuan dan keterampilan nakhoda dan perwira jaga, pengawakan, pendidikan dan pelatihan, ujian dan sertifikasi awak kapal, standar kelaiklautan kapal dan standar ketenagakerjaan pada kapal penangkap ikan diatur tersendiri.

Penelitian bertujuan untuk :

1. Mengidentifikasi kebijakan keselamatan kapal penangkap ikan pada tingkat nasional dan internasional.

2. Menganalisis kebijakan nasional tentang keselamatan kapal penangkap ikan di Indonesia.

3. Keterkaitan kebijakan kapal penangkap ikan dan kapal niaga serta keterkaitan antara internasional dan nasional tentang keselamatan kapal penangkap ikan.

\section{METODOLOGI}

Penelitian dilaksanakan Mei 2008Maret 2009. Sumber data primer diperoleh dari Badan Pengembangan Sumberdaya Manusia Kelautan dan Perikanan, Direktorat Jenderal Perikanan Tangkap dan Pelabuhan Perikanan Pantai (PPP) Tegal Sari Kota Tegal, Pelabuhan Perikanan Nusantara (PPN) Pekalongan, Pelabuhan Perikanan Samudera (PPS) Cilacap dan Kementerian Perhubungan.

Data primer diperoleh dengan mengumpulkan dan menelaah dokumen-dokumen kebijakan nasional maupun internasional dan mengidentifikasi penerapan peraturan keselamatan di lapangan oleh awak kapal atau pemilik kapal.

Data primer kecelakaan kapal diperoleh dari HNSI Cabang Kota Tegal dan Syahbandar PPP Tegalsari, Satpolair PPN Pekalongan dan HNSI Cabang Kab. Cilacap. Sedangkan data sekunder diperoleh dari studi pustaka dari jurnal internasional, internet dan laporan.

Identifikasi terhadap peraturan nasional mencakup peraturan perundangan, peraturan pemerintah, keputusan menteri, keputusan direktur jenderal mengenai kelaiklautan kapal penangkap ikan, pengawakan kapal penangkap ikan, pendidikan dan pelatihan kepelautan kapal penangkap ikan, ujian kompetensi dan sertifikasi, ke- tenagakerjaan pada kapal penangkap ikan, standar operasi penangkapan dan asuransi awak kapal. Identifikasi terhadap kewajiban para pihak terkait dengan keselamatan kapal seperti nakhoda dan anak buah kapal, pemilik kapal, syahbandar dan pihak lainnya.

Identifikasi terhadap peraturan internasional mengenai keselamatan kapal penangkap ikan, standar minimum pengetahuan dan keterampilan awak kapal, standar kapal penangkap ikan, lalulintas di laut dan peraturan internasional lainnya dalam bentuk konvensi, protokol, tata laksana dan standar minimum. Analisis keterkaitan antara peraturan nasional dan internasional.

Peraturan nasional mestinya sudah mengacu dan mengakomodasi peraturan internasional yang relevan mengingat semakin diberlakukannya peraturan internasional. Hal ini sangat penting dalam perkembangan isu-isu global baik dalam hal ekonomi, perdagangan, lingkungan dan ketenagakerjaan.

\section{HASIL PENELITIAN}

\section{A. Identifikasi Peraturan Nasional}

Menurut ILO (2000), peraturan perundangan nasional tentang keselamatan dan kesehatan awak kapal penangkap ikan sangat bervariasi. Hal yang dapat menyulitkan akibat adanya pendekatan kategori kapal yang berbeda seperti panjang kapal, tonase, tenaga mesin dan jangkauan operasi. Di beberapa negara Eropa dan Jepang telah memiliki peraturan berkaitan dengan keselamatan dan kesehatan pada industri perikanan tangkap, sementara di beberapa negara lainnya kurang mengatur seperti Philiphine, China dan Amerika Serikat. Umumnya, semakin kecil ukuran kapal semakin kurang diatur.

Peraturan perundangan tingkat nasional tentang keselamatan kapal perikanan, sebagai berikut:

1. Undang-Undang Nomor 31 Tahun 2004 tentang Perikanan

Undang-Undang Nomor 31 Tahun 2004 sebagaimana telah diubah dengan Undang-Undang Nomor 45 tahun 2009 tentang Perikanan pada Pasal 42 ayat (1), mengamanatkan bahwa dalam rangka keselamatan operasional kapal perikanan, ditunjuk syahbandar di pelabuhan perikanan. Ayat (2a) memiliki fungsi menerbitkan Surat Persetujuan Berlayar; Ayat (2d) memeriksa teknis dan nautis kapal peri- 
kanan dan memeriksa alat penangkapan ikan dan alat bantu penangkapan ikan; Ayat $(2 \mathrm{n})$ memeriksa pemenuhan persyaratan pengawakan kapal perikanan. Pada Pasal 43 mengamanatkan bahwa setiap kapal perikanan yang melakukan kegiatan perikanan wajib memiliki surat laik operasi kapal perikanan dari pengawas perikanan tanpa dikenai biaya.

Setiap kapal yang akan berlayar wajib memiliki Surat Ijin Berlayar (istilah UndangUndang No.17/2008: Surat Persetujuan Berlayar) yang dikeluarkan oleh syahbandar. Pasal 43 mengamanatkan bahwa setiap kapal perikanan yang akan melakukan kegiatan perikanan wajib memiliki Surat Laik Operasi (SLO) kapal perikanan dari pengawas perikanan. Pada Pasal 44 mengamanatkan Surat Ijin Berlayar (SIB) kapal perikanan diterbitkan oleh syahbandar setelah mendapatkan SLO. Terbitnya SIB berarti kapal sudah dinyatakan layak untuk berlayar dan beroperasi menangkap ikan.

Pengembangan sumberdaya manusia pelaut perikanan sebagai faktor dominan dalam terwujudnya budaya keselamatan operasi penangkapan ikan, dalam UndangUndang Nomor 31 Tahun 2004 Pasal 57, 58 dan 59 sebagaimana telah diubah dengan Undang-Undang Nomor 45 Tahun 2009 mengamanatkan bahwa pemerintah menyelenggarakan pendidikan, pelatihan dan penyuluhan perikanan untuk meningkatkan pengembangan sumberdaya manusia perikanan. Sekurang-kurangnya satu satuan pendidikan dan/atau pelatihan untuk dikembangkan menjadi satuan pendidikan dan/atau pelatihan bertaraf internasional serta dapat bekerjasama dengan lembaga terkait baik tingkat nasional maupun internasional.

Implementasi pengembangan sumberdaya manusia pelaut perikanan pada pendidikan formal melalui Program Studi Teknologi Penangkapan Ikan (TPI) dan Program Studi Permesinan Perikanan Akademi Perikanan/Politeknik Perikanan dan Sekolah Tinggi Perikanan serta Program Keahlian Nautika Perikanan Laut (NPL) dan Teknika Perikanan Laut (TPL). Pada pendidikan menengah perikanan, yakni Sekolah Usaha Perikanan Menengah (SUPM) dan Sekolah Menengah Kejuruan (SMK). Kurikulum pendidikan dan/atau pelatihan, staf pengajar, sarana prasarana, serta sistem mutu mengacu pada standar nasional dan internasional STCW-F 1995 dari IMO, melalui pelatihan peningkatan sumberdaya manusia pelaut perikanan atau nelayan melalui pelatihan fungsional kepelautan kapal perikanan pada lembaga pelatihan yang berstandar. Kepada peserta pelatihan yang memenuhi syarat akan mendapatkan sertifikat kompetensi kepelautan.

\section{Undang-Undang Nomor 17 Tahun 2008 tentang Pelayaran}

Undang-Undang Nomor 17 Tahun 2008 diterbitkan sebagai pengganti UndangUndang Nomor 21 Tahun 1992. UndangUndang tersebut telah mengakomodasi peraturan internasional yang telah diratifikasi oleh pemerintah seperti standar pelatihan dan sertifikasi pelaut niaga (STCW-1995) dan ketenagakerjaan di sektor maritim untuk kapal niaga yakni Maritime Labor Convention 2006. Pada undang-undang ini pasal-pasal yang mengatur keselamatan kapal penangkap ikan secara explisit sangat terbatas. Secara umum undang-undang ini mengatur pelayaran niaga. Pada Bab IX Pasal 124 sampai dengan Pasal 150 mengatur kelaik-lautan kapal meliputi: keselamatan kapal, pencegahan pencemaran dari kapal, pengawakan kapal, garis muat kapal dan pemuatan.

Setiap pengadaan, pembangunan dan pengerjaan kapal termasuk perlengkapannya serta pengoperasian kapal di perairan Indonesia harus memenuhi persyaratan keselamatan kapal, meliputi: material; konstruksi; bangunan; permesinan dan perlistrikan; stabilitas; tata susunan serta perlengkapan termasuk perlengkapan alat penolong dan radio; serta elektronika kapal. Kapal yang dinyatakan memenuhi persyaratan keselamatan kapal diberi sertifikat, yakni:

1. Sertifikat keselamatan kapal penumpang;

2. Sertifikat keselamatan kapal barang; dan

3. Sertifikat kelaikan dan pengawakan kapal penangkap ikan.

Undang-Undang No. 17 Tahun 2008 mengamanatkan kewajiban nakhoda sebagai pihak yang memiliki wewenang dan tanggungjawab dan wajib memberitahukan kepada Pejabat Pemeriksa Keselamatan Kapal apabila mengetahui bahwa kondisi kapal atau bagian dari kapalnya, dinilai tidak memenuhi persyaratan keselamatan kapal. Kapal sesuai dengan jenis, ukuran dan daerah pelayarannya wajib dilengkapi dengan peralatan meteorologi dan apabila nakhoda mengetahui adanya cuaca buruk yang membahayakan keselamatan berlayar 
wajib menyebarluaskannya kepada pihak lain.

Setiap kapal wajib diawaki oleh awak kapal yang memenuhi persyaratan kualifikasi dan kompetensi sesuai dengan ketentuan nasional dan internasional. Nakhoda wajib memenuhi persyaratan pendidikan, pelatihan, kemampuan, dan keterampilan serta kesehatan dan dilarang mempekerjakan seseorang di kapal dalam jabatan apapun tanpa disijil dan tanpa memiliki kompetensi dan keterampilan serta dokumen pelaut yang dipersyaratkan.

\section{Peraturan Pemerintah Nomor 7 Tahun} 2000 Tentang Kepelautan

Peraturan Pemerintah (PP) Nomor 7 Tahun 2000 tentang Kepelautan merupakan produk hukum dibawah UndangUndang Nomor 21 Tahun 1992 tentang Pelayaran yang sekarang sudah diganti dengan Undang-Undang Nomor 17 Tahun 2008 tentang Pelayaran. Mengingat belum terbitnya PP yang mengatur kepelautan turunan Undang-Undang Nomor 17 Tahun 2008 tentang Pelayaran maka Peraturan Pemerintah Nomor 7 Tahun 2000 tentang Kepelautan masih belum dicabut.

Bab VI Pasal 41 sampai dengan Pasal 45 PP Nomor 7 Tahun 2000 mengatur mengenai pengawakan kapal, ujian dan sertifikasi pelaut kapal penangkap ikan.

Pengawakan kapal penangkap ikan harus disesuaikan dengan :

a. Daerah pelayaran;

b. Ukuran kapal;

c. Daya penggerak kapal (kilowatt/KW).

4. Peraturan Menteri Perhubungan KM 9 Tahun 2005 Tentang Pendidikan, Pelatihan, Ujian dan Sertifikasi Pelaut Perikanan

Pendidikan dan pelatihan bagi pelaut kapal penangkap ikan sangat penting dalam peningkatan kapasitas sumberdaya manusia awak kapal dan calon awak kapal. Peraturan Menteri ini merupakan penjabaran dari Peraturan Pemerintah Nomor 7 Tahun 2000 tentang Kepelautan. Pada Peraturan Kementerian Perhubungan KM 9 Tahun 2005 Pasal 2 ayat (3) menyebutkan bahwa pendidikan dan pelatihan pelaut kapal penangkap ikan diselenggarakan oleh Menteri yang bertanggungjawab dibidang perikanan dalam hal ini Menteri Kelautan dan Perikanan setelah mendapatkan rekomendasi dari Menteri Perhubungan.

Pendidikan dan pelatihan pelaut kapal penangkap ikan dilaksanakan oleh unit-unit pendidikan dan/atau pelatihan perikanan atau badan hukum pendidikan berdasarkan sistem standar mutu sesuai dengan peraturan perundang-undangan yang berlaku. Ketentuan mengenai sistem standar mutu pendidikan dan pelatihan, ujian dan sertifikasi pelaut kapal penangkap ikan diatur lebih lanjut dengan Peraturan Menteri yang bertanggungjawab dibidang perikanan.

Pendidikan dan pelatihan pelaut perikanan digolongkan menjadi:

1) Pendidikan dan Pelatihan Profesional Pelaut Kapal Penangkap Ikan, merupakan pendidikan formal tingkat menengah dan pendidikan tinggi untuk mendapatkan Sertifikat Keahlian Pelaut Kapal Penangkap Ikan;

2) Pendidikan dan Pelatihan Fungsional Pelaut Kapal Penangkap Ikan, pendidikan nonformal peningkatan jenjang profesi pelaut kapal penangkap ikan;

3) Pendidikan dan Pelatihan Keterampilan Pelaut Kapal Penangkap Ikan pelaut kapal penangkap ikan yakni pendidikan nonformal kecakapan untuk melakukan pekerjaan tertentu pada kapal penangkap ikan.

Ujian Keahlian Pelaut Kapal Penangkap Ikan diselenggarakan oleh dewan mandiri, yakni Dewan Penguji Keahlian Pelaut (DPKP). DPKP dibentuk oleh dan bertanggungjawab kepada Direktur Jenderal Perhubungan Laut. Untuk pelaksanaan ujian kepelautan kapal penangkap ikan di daerah dibentuk Panitia Ujian Keahlian Pelaut Kapal Penangkap Ikan (PUKP-KAPIN) yang berdomisili di daerah seperti di Medan, Pariaman, Jakarta, Tegal, Banyuwangi, Bitung, Ambon dan Sorong.

Sertifikasi Pelaut Kapal Penangkap Ikan terdiri dari Sertifikat Keahlian (Certificate of Competency) Pelaut Kapal Penangkap Ikan dan Sertifikat Keterampilan (Certificate of Proviciency) Pelaut Kapal Penangkap Ikan.

Jenis dan tingkat Sertifikat Keahlian

Pelaut Kapal Penangkap Ikan, terdiri dari :

a. Sertifikat Ahli Nautika Kapal Penangkap Ikan Tingkat I (ANKAPIN-I);

b. Sertifikat Ahli Nautika Kapal Penangkap Ikan Tingkat II (ANKAPIN-II);

c. Sertifikat Ahli Nautika Kapal Penangkap Ikan Tingkat III (ANKAPIN-III);

d. Sertifikat Ahli Teknika Kapal Penangkap Ikan Tingkat I (ATKAPIN-I);

e. Sertifikat Ahli Teknika Kapal Penangkap Ikan Tingkat II (ATKAPIN-II);

f. Sertifikat Ahli Teknika Kapal Penangkap Ikan Tingkat III (ATKAPIN-III); 
g. Sertifikat Rating Kapal Penangkap Ikan.

Sedangkan Jenis Sertifikat Keterampilan Pelaut Kapal Penangkap Ikan, terdiri dari :

a. Sertifikat Keselamatan Dasar Awak Kapal Penangkap Ikan (Basic Safety Trainning for all Fishing Vessel Personnel/BST-F Certificate);

b. Sertifikat Lanjutan Penanggulangan Kebakaran (Advanced Fire Fighting Certificate);

c. Sertifikat Pertolongan Medis Darurat (Medical Emergency First Aid Certificate);

d. Sertifikat Perawatan Medis di atas Kapal (Medical Care on Board Certificate);

e. Sertifikat Simulasi Radar (Radar Simulator Certificate);

f. Sertifikat Simulasi ARPA (ARPA Simulator Certificate);

g. Sertifikat Operator Radio Umum untuk GMDSS (General Radio Operator Certificate/GOC for the GMDSS);

h. Sertifikat Operator Radio Terbatas untuk GMDSS (Restricted Radio Operator Certificate/ROC for the GMDSS);

i. Sertifikat Kecakapan Pesawat Luput Maut dan Skoci Penyelamat (Proficiency in Survival Craft and Rescue Boats Certificate);

j. Sertifikat Perwira Keamanan Kapal (Ship Security Officer Certificate).

Sertifikat-sertifikat Pelaut Kapal Penangkap Ikan diterbitkan oleh Ditjen Perhubungan Laut, Kementerian Perhubungan.

5. Surat Keputusan Menteri Perhubungan Nomor 46 Tahun 1996

Kementerian Perhubungan hingga Desember 2009 masih menggunakan Surat Keputusan Menteri Perhubungan Nomor 46 tahun 1996 Pasal 2 dan 3 sebagai dasar hukum untuk menerbitkan Pas Tahunan Kapal Penangkap Ikan. Pas Tahunan dikeluarkan Adpel atas nama Direktur Jenderal Perhubungan Laut. Pas Tahunan Kapal Penangkap Ikan memuat data nama kapal, tanda panggilan, tempat pendaftaran, tanda pendaftaran, ukuran kapal, tahun pembangunan, merek dan PK mesin, jumlah geladak, bahan kapal dan jumlah balingbaling serta pemilik kapal dan kedudukan pemilik, menyatakan bahwa telah memenuhi persyaratan sebagai kapal penangkap ikan dan berhak berlayar dengan mengibarkan bendera Republik Indonesia.

Sertifikat Kelaikan dan Pengawakan Kapal Penangkap Ikan yang dilengkapi dengan lembaran tambahan mengenai perlengkapan dan pengawakan kapal pe- nangkap ikan diterbitkan atas dasar Surat Keputusan Menteri Perhubungan Nomor 46 tahun 1996 Pasal 2 dan 4. Isi dokumen tersebut memuat data kapal (nama kapal, tanda panggilan, tempat pendaftaran, tonase kotor, tempat dan tanggal pembangunan dan panjang kapal), daerah pelayaran (lokal/restricted area, perairan Indonesia/Indonesian waters atau semua lautan/ocean going).

Sertifikat tersebut menyatakan bahwa kapal sudah diperiksa sesuai dengan ketentuan dari aturan kelaikan kapal yang berlaku dan peraturan perundangan lainnya yang terkait kepada kelaikan dan pengawakan kapal penangkap ikan. Selanjutnya dinyatakan hasil pemeriksaan menunjukkan bahwa kapal telah memenuhi ketentuan tentang keselamatan konstruksi, permesinan, perlengkapan navigasi, alatalat penolong, alat pemadam kebakaran, perlengkapan radio, peralatan pencegah pencemaran dari kapal dan pencegahan pelanggaran di laut, serta kelengkapankelengkapan lainnya yang terkait dengan aturan kelaikan dan pengawakan kapal penangkap ikan. Pemeriksaan kapal kembali dalam kurun waktu empat tahun. Sertifikat diterbitkan adpel atas nama Dirjen Perhubungan Laut. Pada surat keputusan tersebut belum memberikan kelas kapal ikan dan alat keselamatan apa yang harus ada di kapal.

\section{B. Identifikasi Peraturan Internasional}

Peraturan internasional yang dikeluarkan oleh masing-masing lembaga internasional atau kerjasama diantara ketiga badan tersebut, yakni International Maritime Organization (IMO), International Labor Organization ILO dan Food and Agriculture Organization (FAO) berkenaan dengan keselamatan kapal penangkap ikan, sebagai berikut:

1. IMO: The Torremolinos International Convention for the Safety of Fishing Vessels, 1977;

2. FAO/ILO/IMO: Standard of Training Certification and Watchkeeping for Fishing Vessel Personnel (STCW-F) 1995 Convention;

3. IMO: Convention on the International Regulations for Preventing Collisions at Sea, 1972 (COLREGs);

4. ILO: Work in Fishing Convention No.188 and Recommendation No. 199;

5. IMO: International Convention on Maritime Search and Rescue, 1979;

6. FAO/ILO/IMO: Code of Safety for 
Fishermen and Fishing Vessels, Part A Safety and Health Practice;

7. FAO/ILO/IMO: Code of Safety for Fshermen and Fishing Vessels, Part B Safety and Health Requirements for the Construction and Equipment of Fishing Vessels;

8. FAO/ILO/FAO: Voluntary Guidelines for the Design, Construction and Equipment of Small Fishing Vessels;

9. FAO: Code of Conduct for Responsible Fisheries dari FAO;

10. FAO/ILO/IMO: Document for Guidance on Training and Certifications of Fishing Vessel Personnel, 1995;

11. IMO: Model Course 7.05 Skipper on a Fishing Vessel;

12. IMO: Model Course 7.06 Officer in Charge of A Navigational Watch on $A$ Fishing Vessel;

13. IMO: Model Course 7.07 Chief Engineer Officer and Second Engineer Officer on A Fishing Vessel;

14. IMO: Model Course 1.33 Safety of Fishing Operations (support level).

Penjelasan beberapa konvensi internasional internasional di atas secara garis besar, sebagai berikut:

1. IMO: The Torremolinos International Convention for the Safety of Fishing Vessels, 1977.

Konvensi ini diadopsi IMO pada 2 April

1977. Konvensi mengatur standar keselamatan kapal penangkap ikan yang berukuran panjang $24 \mathrm{~m}$ atau lebih tidak termasuk kapal pengangkut ikan, kapal pengolah ikan, kapal latih, kapal patroli dan kapal penangkap ikan untuk tujuan rekreasi dan olahraga. Konvensi ini diberlakukan (entry into force) satu tahun setelah 15 negara mengesahkan (meratifikasi) dengan jumlah agregat kapal penangkap ikan negara-negara tersebut sebanyak 14.000 unit.

Sampai dengan Februari 2009 konvensi ini sudah diratifikasi oleh 17 negara namun agregat jumlah kapal penangkap ikan dari negara-negara peserta baru mencapai 3.400 unit. Negara-negara yang telah meratifikasi konvensi tersebut tersebut adalah: Belanda, Bulgaria, Denmark, Francis, Islandia, Irlandia, Italia, Jerman, Kiribati, Kroasia, Kuba, Liberia, Lithuania, Norwegia, Saint Kitts and Nevis, Spanyol dan Swedia. Dari 17 negara yang telah meratifikasi konvensi tidak ada satupun negara Asia.
Negara-negara perikanan di Asia termasuk Asia Tenggara pernah menyelenggarakan seminar di Beijing RRC pada tanggal 21-24 September 2004, membicarakan permasalahan dalam merespon konvensi menghasilkan Guideline for The Safety of Fishing Vessels of 24 meters and over but less than 45 meters in length operating in the East and South-east Asia Region.

Pengesahan oleh negara-negara yang memiliki armada perikanan tangkap termasuk lambat, mengingat berbagai pertimbangan teknik, diantaranya:

a. Kapal-kapal berbadan ramping yang banyak dioperasikan di Asia, walaupun memiliki panjang kapal $24 \mathrm{~m}$, sulit untuk memenuhi standar Konvensi tersebut karena ruangan-ruangan di kapal sangat terbatas. Lain halnya dengan kapal-kapal Uni Eropa umumnya berbadan lebar sehingga memiliki cukup ruangan sehingga mampu memenuhi konvensi tersebut.

b. Stabilitas kapal berbadan ramping sulit memenuhi standar stabilitas sebagaimana diatur dalam konvensi.

c. Di beberapa negara mengunakan ukuran kapal dengan panjang dalam meter dan ada yang menggunakan panjang kapal atau GT, sedangkan dalam konvensi tersebut belum ada kesetaraan antara panjang kapal dan GT.

d. Pencegahan, pendeteksian dan pemadaman kebakaran sebagaimana pada Konvensi apabila diterapkan pada kapal penangkap ikan dengan panjang 24 meter atau lebih tetapi berbadan ramping sulit untuk dipenuhi.

e. Peralatan Keselamatan yakni penempatan dewi-dewi utama untuk penempatan skoci penolong (rescue boat) atau skoci keselamatan (survival boat) pada kapal-kapal berbadan ramping.

f. Peralatan radio komunikasi dan perlengkapan navigasi modern sulit dipenuhi untuk kapal-kapal penangkap ikan di negara sedang berkembang yang umumnya nelayan tradisional mengingat peralatan tersebut cukup mahal.

Indonesia sampai saat ini belum meratifikasi konvensi tersebut dengan berbagai pertimbangan teknis dan nonteknis diantaranya bahwa kapal-kapal penangkap ikan di Indonesia menghadapi kesulitan teknis sebagaimana di atas juga mempertimbangkan bahwa armada kapal penangkap ikan di Indonesia 94\% berbobot kurang dari 5 GT. Apabila konvensi ini 
diamandemen berkaitan dengan akan dimasukkannya kesetaraan kriteria panjang kapal dengan GT dimana panjang kapal $24 \mathrm{~m}$ setara dengan 300 GT maka kapalkapal di Indonesia yang terkena peraturan kurang lebih hanya 30 kapal penangkap ikan.

2. FAO/ILO/IMO Standard of Training Certification and Watchkeeping for Fishing Vessel Personnel (STCW-F) 1995

Konvensi diadopsi pada konferensi yang diselenggarakan oleh IMO, dari tanggal 26 Juni sampai 7 Juli 1995. Konferensi yang dihadiri 74 negara termasuk Indonesia tersebut mengadopsi Konvensi STCW-F 1995 dan sembilan resolusi pada lampirannya. Tujuan diterbitkannya konvensi STCW-F 1995 adalah untuk meningkatkan keselamatan jiwa dan harta benda di laut serta perlindungan lingkungan laut dengan menetapkan melalui kesepakatan bersama standar-standar internasional pelatihan, sertifikasi dan dinas jaga bagi orang yang bertugas di atas kapal penangkap ikan.

Konvensi ini mengatur standar persyaratan pengetahuan dan keterampilan minimum sertifikasi awak kapal penangkap ikan berukuran panjang 24 meter atau lebih, serta prinsip-prinsip dinas jaga laut. Pengaturan standar persyaratan minimum untuk sertifikasi awak kapal penangkap ikan tersebut, yakni:

1. Persyaratan minimum yang diwajibkan untuk sertifikasi nakhoda kapal penangkap ikan panjang 24 meter atau lebih yang beroperasi di perairan tak terbatas;

2. Persyaratan minimum yang diwajibkan untuk sertifikasi perwira yang melaksanakan tugas jaga navigasi pada kapal penangkap ikan dengan panjang 24

8 meter atau lebih yang beroperasi di perairan tak terbatas;

3. Persyaratan minimum yang diwajibkan untuk sertifikasi nakhoda kapal penangkap ikan dengan panjang 24 meter atau lebih yang beroperasi di perairan terbatas;

4. Persyaratan minimum yang disyaratkan untuk sertifikasi perwira jaga navigasi di kapal penangkap ikan dengan panjang 24 meter atau lebih yang beroperasi di perairan terbatas;

5. Persyaratan minimum yang diwajibkan untuk sertifikasi Kepala Kamar Mesin dan Masinis II pada kapal penangkap ikan yang digerakkan oleh mesin penggerak utama dengan daya dorong 750 kW atau lebih;
6. Persyaratan minimum yang disyaratkan untuk sertifikasi GMDSS bagi petugas radio di kapal penangkap ikan;

7. Tambahan pengetahuan dan pelatihan minimum yang disyaratkan bagi petugas radio GMDSS;

8. Persyaratan wajib minimum untuk menjamin keberlanjutan kecakapan dan pemutakhiran pengetahuan bagi nakhoda, perwira dan perwira mesin;

9. Pelatihan keselamatan tingkat dasar bagi seluruh awak kapal penangkap ikan (Basic Safety Training for all fishing vessels personnel);

10. Prinsip dasar yang harus diamati dalam jaga navigasi pada kapal penangkap ikan.

Dalam Konvensi STCW-F 1995 juga dimuat sembilan resolusi pada Lampiran 2 konvensi. Konvensi diberlakukan (entry into force) 12 bulan setelah tidak kurang dari 15 negara menandatangani tanpa syarat sebagai ratifikasi, penerimaan atau persetujuan atau telah menyampaikan instrumen ratifikasi, penerimaan, persetujuan atau penambahan anggota.

Pemerintah Indonesia hingga saat ini belum meratifikasi STCW-F 1995, namun dalam pengembangan pendidikan dan pelatihan bertaraf internasional bidang kepelautan perikanan, kurikulum, sarana prasarana dan tenaga pengajar telah mengacu kepada Konvensi STCW-F 1995 dan sedang disiapkan dokumen-dokumen pengesahan Konvensi STCW-F 1995.

Hingga Februari 2009 negara-negara yang telah mengesahkan STCW-F 1995 sudah 14 negara, yakni Denmark, Faroe Islands, Federasi Russia, Francis, Islandia, Kiribati, Latvia, Maroko, Mauritania, Norwegia, Spanyol, Sierra Leone, Syirian Arab Republic dan Ukraina.

3. Convention on the International Regulations for Preventing Collisions at Sea, 1972 (COLREGs)

Konvensi mengatur tata lalulintas di laut dimaksudkan untuk mencegah tubrukan di laut. Konvensi diadopsi IMO pada tahun 1972 dan memasuki masa pemberlakuan 15 Juli 1977 sebagai pengganti Peraturan Pencegahan Tubrukan Tahun 1960. Konvensi mengatur pelayaran pada berbagai kondisi perairan, kecepatan yang aman, berlayar pada alur pelayaran dengan jalur pemisah, kapal berlayar saling melihat, berlayar pada jarak pandang terbatas, tindakan-tindakan yang harus dilakukan dalam menghindari tubrukan. Konvensi juga mengatur isyarat bunyi, 
cahaya dan sosok benda yang digunakan pada sistem lalulintas di laut. Indonesia sudah menggunakan peraturan lalulintas untuk mencegah tubrukan di laut sebagaimana dalam konvensi yang diadopsi tahun 1960 maupun yang terbaru 1972. Tidak kurang dari 157 negara telah meratifiksi konvensi ini.

4. Document for Guidance on Training, Certification and Watchkeeping of Fishing Vessel Personnel, 1995.

Kelompok Kerja FAO/ILO/IMO menghasilkan suatu dokumen yang telah ditinjau kembali berjudul Document for Guidance on Training, Certification and Watchkeeping of Fishing Vessel Personnel. Dokumen ini merupakan panduan pelatihan dan sertifikasi sebagai turunan konvensi STCW-F 1995.

Dokumen panduan pelatihan, sertifikasi dan dinas jaga, sebagai berikut:

Pada Bagian A memuat prinsipprinsip umum standar dan program pelatihan, tenaga pengajar, metode pelatihan, pelatihan prakejuruan, kejuruan dan lanjutan, ujian dan minimum persyaratan untuk sertifikasi kepelautan termasuk umur minimum, kesehatan dan pelayanan sertifikasi serta masalah kelelahan awak kapal kaitannya dengan dinas jaga.

Bagian B dokumen mengatur unit kompetensi minimum yang harus dipenuhi untuk sertifikasi pelaut kapal penangkap ikan bagi kapal-kapal penangkap ikan berukuran kecil (panjang kapal < 12 meter). Terdapat 34 mata pelatihan yang harus diikuti oleh peserta pelatihan kepelautan kapal penangkap ikan berukuran kecil. Hal tersebut dimuat dalam Bab III.

Bagian C memuat kapal penangkap ikan yang memiliki dek dengan panjang 12 meter sampai dengan kurang dari 24 meter, dimuat dalam Bab IV.

Bagian D memuat kapal penangkap ikan dengan panjang 24 meter dan lebih atau memiliki tenaga penggerak utama 750 kw atau lebih.

Sedangkan pada lampiran memuat silabus 42 jenis pelatihan, diantaranya pelatihan: Pelatihan Prosedur Darurat bagi nakhoda dan perwira jaga; Pelatihan Automatic Radar Plotting Aids (ARPA); Kursus Radar Simulator; Pelatihan bagi nakhoda dan perwira jaga navigasi dalam Penanganan dan Olah Gerak Kapal Penangkapan Ikan; Pelatihan Perwira Mesin dalam Penanganan dan Olah Gerak Kapal Penangkap Ikan; Perikanan yang Bertang- gungjawab; Prinsip-Prinsip Pengamatan pada saat Tugas Jaga Mesin.

5. ILO, Work in Fishing Convention (Convention No. 188 and Recommen-dation 199)

Sidang Ketenagakerjaan Internasional (ILC) ke-96 yang berlangsung pada tanggal 29 Mei s.d. 15 Juni 2007 antara lain membahas rancangan Konvensi ILO tentang Ketenagakerjaan di Sektor Perikanan Tangkap. Rancangan konvensi tersebut telah dibahas sejak Sidang ILC ke-93 tahun 2004 dan pada ILC ke-94 tahun 2005 .

Ruang lingkup konvensi dibatasi dalam lingkup commercial fishing yang mencakup semua kapal ikan yang beroperasi untuk melakukan penangkapan ikan, kecuali kapal ikan untuk memenuhi kebutuhan sehari-hari (subsistence fishing). Apabila istilah commercial fishing ini diterapkan terhadap kapal-kapal ikan yang mempunyai ijin usaha penangkapan ikan di Indonesia, maka sebagian besar kapal-kapal ikan tersebut masuk dalam kategori kapal ikan komersial. Kapal penangkap ikan di Indonesia yang jumlahnya begitu besar pada umumnya dirancang dan dibangun di galangan kapal lokal dengan teknologi sederhana (tradisional), sehingga tidak ada jaminan bahwa kapal tersebut telah memenuhi standar keamanan.

Kapal-kapal berukuran 24 meter ke atas milik nelayan belum dirancang sebagaimana diatur dalam konvensi rancangan konstruksi kapal, tinggi langit-langit ruangan, insulasi ruangan, getaran dan kebisingan, ventilasi, lampu penerangan, AC, luas lantai ruang tidur, tempat dan peralatan ruang tidur, sanitasi, akomodasi dan fasilitas rekreasi.

Perjanjian Kerja (Work Agreement) yang didalamnya mengatur sistem pengupahan dan sistem bagi hasil, serta sistem hubungan kerja antara pekerja dan pengusaha, diwajibkan untuk dibuat secara tertulis bagi kapal-kapal penangkap ikan yang mempekerjakan awak kapal. Di sektor perikanan tangkap umumnya masih menganut sistem bagi hasil. Selama ini hubungan antara pemilik kapal dan awak kapal dalam sistem bagi hasil masih didasarkan atas kesepakatan yang tidak tertulis. Banyak diantara pemilik kapal juga merangkap sebagai awak kapal. Oleh karena itu tanggungjawab antara pemilik kapal (employyer), nahkoda (skipper), dan anak buah kapal (ABK) sebagaimana diatur dalam konvensi belum dapat dilaksanakan secara utuh. 
Tingkat pendapatan nelayan sangat dipengaruhi oleh produktivitas yang diperoleh berdasarkan sistem bagi hasil. Dalam sistem bagi hasil ini, semua upaya dan pengeluaran yang berkaitan dengan peningkatan keamanan serta keselamatan dan kesehatan kerja menjadi tanggungan sepenuhnya para nelayan. Konvensi juga mengatur tentang kriteria pengawakan kapal-kapal penangkap ikan, yang dalam kondisi saat ini belum dapat dipenuhi oleh sebagian besar awak kapal yang memiliki sertifikasi kompetensi pelaut kapal penangkap ikan.

Untuk melaksanakan pengawasan penerapan konvensi dibutuhkan sumberdaya manusia pengawas ketenagakerjaan, hal ini dapat ditambahakan kepada tupoksi pengawas sumberdaya kelautan dan perikanan yang ada saat ini. Sampai saat ini belum ada satu negarapun yang meratifikasi konvensi tetapi masih dalam tahap sosialisasi dan peneltian mendalam tentang manfaat konvensi.

\section{IMO Model Course 7.05 Skipper on a Fishing Vessel}

Model Course 7.05 merupakan skim pelatihan untuk nakhoda kapal penangkap ikan berukuran panjang 24 meter atau lebih yang beroperasi di perairan tak terbatas atau laut dalam. Setelah peserta mengikuti pelatihan dengan sempurna dan ditambah pengalaman berdinas jaga, nakhoda akan lebih mampu melaksanakan tugas dan tanggungjawab secara penuh tentang keselamatan kapal, awak kapal dan hasil tangkapan. Standar kopetensi yang harus dipenuhi sesuai standar yang tertuang dalam konvensi STCW-F 1995.

\section{IMO Model Course 1.33 Safety of Fishing Operations (support level)}

Model pelatihan pendek bagi kelasi (bukan perwira) yang dikembangkan IMO dalam kaitannya dengan pemenuhan standar kompetensi keselamatan kapal penangkap ikan sesuai dokumen STCW-F 1995. Struktur model pelatihan didasarkan pada peraturan STCW-F 1995 Regulation 1 yakni Basic Safety Training for All Fishing Vessel Personnel, bahwa awak kapal harus memperoleh pelatihan keselamatan dasar yang disetujui oleh Administration IMO, dalam hal ini Dirjen Perhubungan Laut Kementerian Perhubungan, meliputi:

1) Teknik penyelamatan diri termasuk cara penggunaan jaket penolong dan bila memungkinkan pakaian cebur (personal survival techniques, including donning of lifejackets and, as appropriate, immersion suits);

2) Pencegahan dan pemadaman kebakaran (Fire prevention and fire fighting);

3) Prosedur darurat (Emergency procedures);

4) Pertolongan pertama pada kecelakaan (Elementary first aid);

5) Pencegahan polusi laut (prevention of marine polution);

6) Pencegahan kecelakaan di atas kapal (prevention of shipboard accidents).

8. FAO/ILO/FAO Voluntary Guidelines for the Design, Construction and Equipment of Small Fishing Vessels

Panduan ini bersifat voluntir, diterbitkan bersama pada tahun 1980 oleh IMO atas nama ketiga lembaga PBB yakni FAO/ILO/IMO. Panduan ini mengatur desain, konstruksi dan perlengkapan kapal bagi kapal-kapal berukuran kecil yang baru. Berukuran kecil menurut IMO adalah kapal-kapal penangkap ikan yang berukuran panjang length of waterline (LWL) antara 12 meter sampai kurang dari 24 meter.

9. Code of Safety for Fshermen and Fishing Vessels.

Part A: Safety and Health Practice 2005.

Tata laksana ini bersifat voluntir. Ketiga badan PBB yang terkait dengan peraturan ini bersepakat sesuai dengan kompetensi masing-masing, yaitu:

FAO, masalah perikanan secara umum;

ILO, masalah ketenagakerjaan dalam industri perikanan;

IMO, masalah keselamaatan jiwa, kapal dan perlengkapannya di laut.

Tata laksana bagian A (Part A) ditujukan kepada nakhoda dan anak buah kapal berkaitan dengan persyaratan operasional dan pekerjaan di atas kapal penangkap ikan. Tata laksana dimaksudkan untuk menyediakan informasi dalam mempromosikan keselamatan dan kesehatan awak kapal pada kapal penangkap ikan, definisi, kerjasama dan survei serta menjelaskan tugas dan tanggung jawab pihak yang berwenang (competent authorities), pemilik kapal, nakhoda, anak buah kapal (ABK) dan lembaga pendidikan dan pelatihan yang berkenaan penyelenggara pendidikan dan pelatihan keselamatan dan kesehatan bagi awak kapal/calon awak kapal penangkap ikan.

Pada Seksi II mengatur keselamatan kapal-kapal berukuran panjang kurang dari 12 meter. Sedangkan pada Seksi III mengatur keselamatan kapal berukuran panjang kapal di atas 12 meter. 
10. Code of Safety for Fishermen and Fishing Vessels.

Part B: Safety and Health Require-ments for the Construction and Equipment of Fishing Vessels 2005.

Tata laksana bagian B ditujukan kepada pihak pembangun kapal dan pemilik kapal berkaitan dengan persyaratan konstruksi dan perlengkapan kapal penangkap ikan. Peraturan ini bersifat voluntir dan diterbitkan dalam rangka menyediakan informasi berkaitan dengan desain, konstruksi dan perlengkapan kapal penangkap ikan dari titik pandang menggalakkan keselamatan kapal penangkap ikan dan keselamatan serta kesehatan awak kapal.

Pada Bab I memuat tujuan, dan definisi. Dilanjutkan Bab II mengatur konstruksi dan bagian kapal yang harus kedap air serta perlengkapan kapal. Sedangkan pada Bab III berkaitan dengan stabilitas kapal dan kelaiklautan kapal. Pada Bab IV diatur mengenai instalasi permesinan dan listrik kapal serta penanganan ruang-ruangan mesin yang terisolasi. Bab $\mathrm{V}$ memuat masalah proteksi, deteksi, dan pemadaman kebakaran. Pada Bab VI memuat perlindungan awak kapal. Sedangkan pada Bab VII sampai Bab X memuat informasi peralatan keselamatan dan penempatannya, prosedur darurat, radio komunikasi, peralatan navigasi dan akomodasi awak kapal.

\section{Keterkaitan Peraturan Nasional deng- an Peraturan Internasional}

Ketentuan hukum bagi keselamatan kapal dan inspeksinya di setiap negara sering mendikte/kerangka program pelatihan. Jika kerangka tidak ada, maka perlu dibuat sebaiknya sebagai bagian integral dari pengelolaan perikanan dalam konteks yang lebih luas. Kerangka untuk perundang-undangan seperti itu dapat dikerjakan oleh pemerintah nasional dalam kerjasama erat dengan para pemangku kepentingan seperti pemilik kapal, asosiasi nelayan dan kelompok-kelompok pengguna sesuai dan disesuaikan dengan kebutuhan spesifik dari masing-masing Negara. Hal ini penting untuk memastikan bahwa peraturan telah mempertimbangkan berbagai sifat kegiatan perikanan. Aturan yang mungkin sesuai untuk jenis pakan tertentu tidak selalu berlaku untuk jenis kapal atau perikanan lain. Undang-undang yang tidak sesuai adalah kontraproduktif, karena akan dianggap sebagai hal yang tidak realistis dan tidak dapat diterapkan, sehingga menim- bulkan ketidakpatuhan (Jeremy Tuner, FAO 2005). Tabel 1 menggambarkan beberapa peraturan nasional tentang kapal penangkap ikan yang dikaitkan dengan peraturan internasional.

\section{KESIMPULAN DAN SARAN}

1. Hasil identifikasi peraturan perundangan tentang keselamatan kapal penangkap ikan mengacu kepada UU No.31/2004, UU No 45/2009, UU No.17/2008, PP 7/2000, Peraturan Menteri KM 9/2005, Surat Keputusan Menhub No.46/1996. Peraturan keselamatan kapal penangkap ikan masih diwarnai peraturan yang diwajibkan bagi kapal niaga dan belum mengacu peraturan internasional untuk kapal penangkap ikan.

2. Belum ada pengaturan standar kapal penangkap, ketenagakerjaan, endorsemen dan pengawakan pada kapal penangkap ikan.

3. Identifikasi terhadap peraturan internasional yang mengatur keselamatan kapal penangkap ikan paling tidak teridentifikasi lima konvensi, tiga Tata laksana dan satu panduan (guideline) yang umumnya diwajibkan bagi kapalkapal berukuran panjang $24 \mathrm{~m}$ atau lebih sementara armada perikanan dunia $80 \%$ kapal berukuran panjang kurang dari $24 \mathrm{~m}$. Pengaturan meliputi standar kapal, standar kualifikasi nakhoda dan perwira jaga, ketenaga kerjaan, pendidikan dan pelatihan, ujian dan sertifikasi, skim pelatihan nakhoda dan kelasi kapal, peraturan untuk mencegah tubrukan di laut, dan penangkapan ikan yang bertanggungjawab. Badan penerbit peraturan internasional untuk keselamatan kapal penangkap ikan yakni IMO, ILO dan FAO baik secara sendiri-sendiri atau saling bekerjasama.

4. Peraturan nasional yang belum menga$\mathrm{cu}$ peraturan internasional yang relevan mencakup pengaturan standar kapal penangkap ikan, ketenagakerjaan dan pengawakan.

5. Mengingat karakteristik pekerjaan pada kapal penangkap ikan berbeda sekali dengan kapal lainnya maka disarankan pengaturan keselamatan awak kapal, standar kapal penangkap ikan, pengawakan, persyaratan kerja pada kapal penangkap ikan, pendidikan dan pelatihan serta ujian dan sertifikasi diatur tersendiri. 
6. Perlu pengkajian dan sosialisasi lebih mendalam kemungkinan meratifikasi STCW-F 1995 dan Torremolinos Safety of Fishing Vessel Convention 1977.
Perlu adanya harmonisasi antara peraturan nasional terhadap peraturan internasional tentang kapal penangkap ikan.

Tabel 1. Pengaturan Internasional dan nasional tentang Kapal Niaga dan Kapal Penangkap Ikan

\begin{tabular}{|c|c|c|c|c|c|}
\hline No. & $\begin{array}{l}\text { Ruang lingkup } \\
\text { peraturan }\end{array}$ & $\begin{array}{c}\text { Peraturan } \\
\text { Internasional } \\
\text { Kapal Niaga }\end{array}$ & $\begin{array}{c}\text { Peraturan } \\
\text { Internasional } \\
\text { Kapal Ikan }\end{array}$ & $\begin{array}{c}\text { Peraturan } \\
\text { Nasional Kapal } \\
\text { Ikan }\end{array}$ & Keterangan \\
\hline 1. & Standar Kapal & SOLAS & $\begin{array}{l}\text { Torremolinos } \\
\text { Safety of } \\
\text { Fishing Vessel } \\
\text { Convention } \\
1977\end{array}$ & $\begin{array}{l}\text { Rujukan masih } \\
\text { SOLAS, }\end{array}$ & $\begin{array}{l}\text { Perlu mengembangkan pengaturan standar } \\
\text { nasional kapal penangkap ikan berukuran } \\
\text { kecil mengingat armada kapal didominasi } \\
\text { kapal kecil, sedangkan untuk kapal }>300 \mathrm{GT} \\
\text { perlu mengacu Konvensi Torremolinos Safety } \\
\text { of Fishing vessel Convension. }\end{array}$ \\
\hline 2. & $\begin{array}{l}\text { Standar } \\
\text { kualifikasi } \\
\text { awak kapal }\end{array}$ & $\begin{array}{l}\text { STCW } 1995 \\
\text { (IMO/ILO) }\end{array}$ & $\begin{array}{ll}\text { STCW-F } & 1995 \\
\text { (FAO/ } & \\
\text { ILO/IMO) } & \end{array}$ & $\begin{array}{l}\text { Sudah mengacu } \\
\text { ke STCW-F } 1995\end{array}$ & Belum ratifikasi STCW-F 1995 \\
\hline 3. & $\begin{array}{l}\text { Persyaratan } \\
\text { Pekerjaan di } \\
\text { atas kapal }\end{array}$ & $\begin{array}{l}\text { Maritime Labor } \\
\text { Convention } \\
\text { (ILO) } 2006\end{array}$ & $\begin{array}{l}\text { Works in } \\
\text { Fishing } \\
\text { Convention } \\
188 \text { dan } \\
\text { Recommen- } \\
\text { dation } 199 \\
\text { (ILO) }\end{array}$ & $\begin{array}{l}\text { Belum ada } \\
\text { pengaturan } \\
\text { ketenaga- } \\
\text { kerjaan untuk } \\
\text { perikanan } \\
\text { tangkap dan } \\
\text { perlu mengacu } \\
\text { Konvensi ILO } \\
\text { No.188 dan } 199\end{array}$ & $\begin{array}{l}\text { MLC dan STCW } 1995 \text { kapal niaga telah } \\
\text { diakomodasi dalam UU No.17/2008, } \\
\text { sedangkan Konvensi } 188 \text { dan Recom } 199 \\
\text { belum dimuat dalam peraturan nasional. }\end{array}$ \\
\hline 4. & $\begin{array}{l}\text { Pengawakan } \\
\text { Kapal }\end{array}$ & $\begin{array}{l}\text { STCW } 1995 \\
\text { (IMO/ILO) }\end{array}$ & $\begin{array}{l}\text { STCW-F } 1995 \\
\text { (FAO/ILO/ } \\
\text { IMO) }\end{array}$ & $\begin{array}{l}\text { Belum ada } \\
\text { pengaturan } \\
\text { pengawakan } \\
\text { kapal ikan yang } \\
\text { sesuai UU } \\
\text { No. } 17 / 2008 \\
\end{array}$ & $\begin{array}{l}\text { Perlu segera pengaturan pengawakan kapal } \\
\text { penangkap dan kapal pengangkut ikan. }\end{array}$ \\
\hline 5. & Endorsement & Sudah diatur & $\begin{array}{l}\text { Sudah diatur } \\
\text { pada KM 9/ } \\
2005 \text { tetapi } \\
\text { sertifikat } \\
\text { endorsemen } \\
\text { belum } \\
\text { diterbitkan } \\
\end{array}$ & $\begin{array}{l}\text { Belum diatur } \\
\text { pada tingkat } \\
\text { direktorat } \\
\text { jenderal }\end{array}$ & $\begin{array}{l}\text { Perlu pengaturan pada tingkat } \\
\text { jenderal direktorat } \\
\text { endorsemen. }\end{array}$ \\
\hline 6. & $\begin{array}{l}\text { Identitas } \\
\text { Pelaut dan } \\
\text { sertifikat BST }\end{array}$ & $\begin{array}{l}\text { SID Konvnesi } \\
\text { ILO } 185\end{array}$ & $\begin{array}{l}\text { SID } \\
\text { Konvensi ILO } \\
185\end{array}$ & $\begin{array}{l}\text { Dokumen pelaut } \\
\text { kapal penangkap } \\
\text { ikan belum } \\
\text { sesuai. }\end{array}$ & $\begin{array}{l}\text { BST-F lebih sesuai untuk dimiliki oleh para } \\
\text { pelaut kapal penangkap ikan bukan BST. } \\
\text { Dan perlu penetapan BST-F khusus awak } \\
\text { kapal-kapal penangkap ikan }<60 \text { GT }\end{array}$ \\
\hline 7. & Ukuran kapal & $\begin{array}{l}\text { Nasional: GT } \\
\text { Konvensi } \\
\text { STCW: GT }\end{array}$ & $\begin{array}{l}\text { Nasional: GT } \\
\text { Internasional:M } \\
\text { eter }\end{array}$ & $\begin{array}{lr}\text { Belum } & \text { ada } \\
\text { kesetaraan } & \\
\text { ukuran kapal } \\
\text { dalam GT dan } \\
\text { meter } & \text { pada } \\
\text { peraturan } & \\
\text { nasional } & \\
\end{array}$ & $\begin{array}{l}\text { Diperlukan ketetapan kesetaraan dalam } \\
\text { peraturan mengingat peraturan nasional } \\
\text { mengacu peraturan internasional }\end{array}$ \\
\hline
\end{tabular}

\section{DAFTAR PUSTAKA}

Departemen Kelautan dan Perikanan dan Japan International Cooperation Agency, 2009. Indonesian Fisheries Statistics Index 2009. Direktorat Jenderal Perikanan Tangkap. Departemen Kelautan dan Perikanan.

Departemen Perhubungan, 2008. UndangUndang Nomor 17 Tahun 2008 Tentang Pelayaran. Peraturan Perundangan Bidang Transportasi. Jakarta.
Departemen Perhubungan, 2005. Peraturan Pemerintah Nomor 7 Tahun 2000 Tentang Kepelautan. Peraturan Perundangan Bidang Transportasi. Jakarta.

Departemen Perhubungan, 2006. Peraturan Menteri Perhubungan Nomor 9 Tahun 2005 Teantang Pendidikan, Pelatihan, Ujian dan Sertifikasi Pelaut Perikanan. Peraturan Perundangan Bidang Transportasi. Jakarta.

Direktorat Jenderal Perikanan Tangkap, 2008. Statistik Perikanan Tangkap 
2008. Direktorat Jenderal Perikanan Tangkap. Departemen Kelautan dan Perikanan.

Food and Agriculture Organization, 2000. The State of World Fisheries and Aquaculture. Part 2. Selected Issues Facing Fishers and aquaculturists. Rome, Italy.

Food and Agriculture Organization, 2007. Text Convention Works in Fishing Sector. Provisional Record No.12A. Ninety-sixth Session. Geneva. Swiss.

International Maritime Organization, 1995. 1993 Torremolinos Protocol and Torremolinos International Convention for the Safety of Fishing Vessels, Consolidated Edition, 1995. London

International Maritime Organization, 1996. International Convention on Satandars of Training, Certification and Watchkeeping for Fishing Vessel Personnel, 1995. London.

International Maritime Organization, International Labor Organization, and Food Agriculture Organization, 2006. Code of Safety for Fishermen and Fishing Vessels 2005. Part B. Safety and Health Requierements for The Construction and Equipment of Fishing Vessel. London.

International Maritime Organization (2001). Document for Guidance on Training and Certification of Fishing Vessel Personnel. 2001 Edition. FAO of United Nations, ILO and IMO, International Labor Organization, and Food Agriculture Organization, 2006. Code of Safety for Fishermen and Fishing Vessels 2005.

International Maritime Organization, 2005. IMO Model Course 1.33. Safety of Fishing Operations (Support Level). 2005 Edition. Course + Compedium. London.
International Maritime Organization, 2005. IMO Model Course 7.05. Skipper on a Fishing Vessel. 2008 Edition. London.

International Maritime Organization, International Labor Organization, and Food Agriculture Organization, 2006. Code of Safety for Fishermen and Fishing Vessels 2005. Part A. Safety and Health Practice. London.

International Labor Organization, and Food Agriculture Organization, 2006. Code of Safety for Fishermen and Fishing Vessels 2005. Part B. Safety and Health Requirements for the Construction and Equipment of Fishing Vessels. London.

Lincoln, Jennifer et al, 2002. Proceedings of the International Fishing Industry Safety and Health Conference. U.S. Department of Health and Human Services, Public Health Service, Center for Disease Control and Prevention, National Institute for Occupational Safety and Health, Occupational Health Program, Department of Environmental Health, Harvard School of Public Health. Massachusetts, U.S.A.

PPN Pekalongan, 2007. Statistik Pelabuhan Perikanan Nusantara Pekalongan, 2007. Pelabuhan Perikanan Nusantara Pekalongan. Direktorat Jenderal Perikanan Tangkap.Departemen Kelautan dan Perikanan.

PPP Tegalsari, 2007. Data Kapal Perikanan Aktif. Kapal Lokal dan Kapal Pendatang, 2007. Pelabuhan Perikanan Pantai, Dinas Perikanan dan Kelautan Provinsi Jawa Tengah.

PPS Cilacap, 2007. Laporan Tahunan, Tahun 2007. Pelabuhan Perikanan Samudera Cilacap. Direktorat Jenderal Perikanan Tangkap. Departemen Kelautan dan Perikanan. 